\title{
Energy Cost Estimation for a Dairy Wastewater Treatment Plant in Terms of Organic Load
}

\author{
*Pelin Yapıcıoğlu \\ *Faculty of Engineering, Department of Environmental Engineering, Harran University, Turkey
}

\begin{abstract}
Energy demand of a wastewater treatment plant is mainly based on the volume of wastewater treated and organic load. In order to obtain energy efficiency in wastewater treatment plants, these significant parameters should be considered. Dairy wastewater has a high organic content. In this study, the impact of design organic loading parameter on energy cost for a dairy wastewater treatment plant was investigated. The aim of the study is in order to reveal the role of design biological oxygen demand on energy efficiency. A new development model that is energy cost indicator has been used. This index was figured out for both design organic load and operational organic load. The results revealed that energy cost indicator of operational organic load was higher than design organic load that were $2.1 \times 10^{-8}$ and $7.2 \times 10^{-18}$, respectively. If WWTPs are operated at design organic load, energy cost would be lower.
\end{abstract}

Key words: Energy cost, $\mathrm{BOD}_{5}$, dairy wastewater treatment plant, organic load

\section{Introduction}

Wastewater treatment plants (WWTPs) are widely used to protect the receiver water bodies from hazardous wastewater discharges [1]. These plants are regarded as one of the top energy consumers [2,3]. High energy consumption causes the high operational costs of the WWTPs. Energy demand of a plant majorly depends on two operational parameters which are the volume of treated wastewater (wastewater flow rate) and organic load (biological oxygen demand $\left(\mathrm{BOD}_{5}\right)$, chemical oxygen demand, total organic carbon etc.) [4]. It should be focused on these two operational parameters in order to provide energy efficiency and to minimize the energy costs in WWTPs. Especially for industrial wastewater treatment plants, organic loading rate and wastewater flow vary in general.

Operational parameters of the industrial WWTPs do not match the design parameters. This mismatch can be originated from the change of production capacity, various process water usages and the modifications of process types for industrial wastewater treatment plants. This mismatch has a negative impact on the performance of the WWTPs and their energy costs. Among industries, the dairy industry is one of the most pollutant plants due to the wastewater generated and discharging highly organic wastewaters $[5,6]$. The dairy industry, like most other agroindustries, generates strong wastewaters characterized by high biological oxygen demand (BOD) and chemical oxygen demand (COD) concentrations representing their high organic content [7].

*Corresponding author: Pelin Yapıcıoğlu Address: Faculty of Engineering, Department of Environmental Engineering, Harran University, Turkey, Şanlıurfa TURKEY. E-mail address: pyapicioglu@ harran.edu.tr, Phone: $+904143181460$ 
This paper aims to reveal the role of design organic load on energy efficiency and cost. The effect of design organic loading parameter $\left(\mathrm{BOD}_{5}\right)$ for a dairy wastewater treatment plant on energy cost was investigated and benchmarked with the operational organic load by using energy cost indicators.

\section{Materials and Method}

\subsection{Description of the dairy wastewater treatment plant}

The dairy industry is located in Turkey. The main products are drinking milk, fruit juice, cream, milk powder, yoghurt and butter. The main wastewater resources are the clarification, pasteurization and homogenization processes. The wastewater plant's characteristics used in this study were given in Table 1 . The wastewater analysis results were performed using Standard Methods [8]. This plant is a type of small-scale plants. Figure 1 shows the wastewater treatment process flow diagram.

Table 1. Data Set of Dairy WWTP

\begin{tabular}{cc}
\hline Parameter & Value \\
\hline Operational flow rate $(\mathrm{Q})$ & $2100 \mathrm{~m}^{3} / \mathrm{d}$ \\
Design flow rate $(\mathrm{q})$ & $3500 \mathrm{~m}^{3} / \mathrm{d}$ \\
Operational biological oxygen demand (BOD 5, operational) & $6.48 \mathrm{~g} / \mathrm{m}^{3}$ \\
Design biological oxygen demand (BOD, design $)$ & $8.0 \mathrm{~g} / \mathrm{m}^{3}$ \\
\hline
\end{tabular}




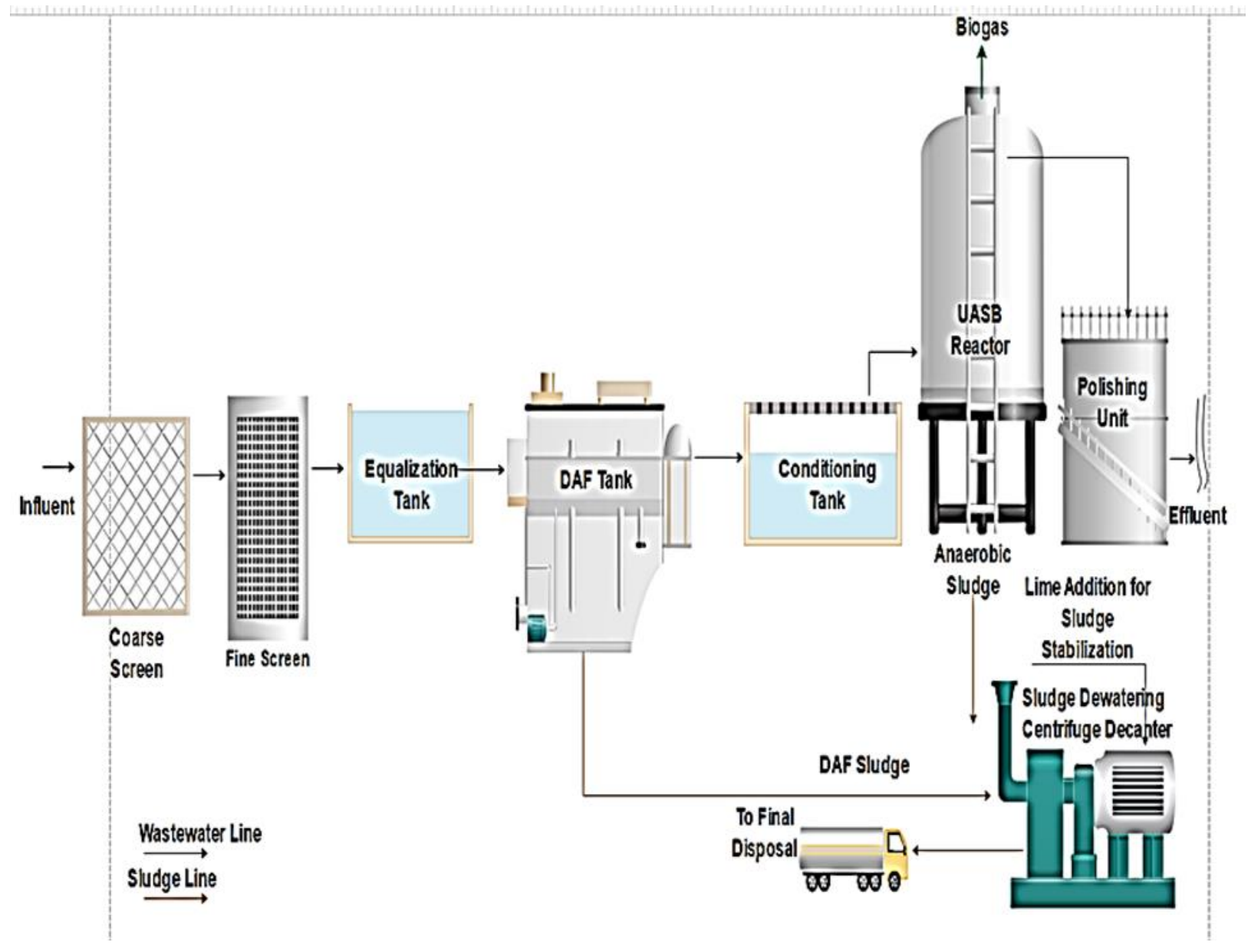

Figure 1. Wastewater treatment process flow diagram of the dairy industry

\subsection{Energy Cost Indicator (ECI) Calculation}

Energy cost assessment is based on the model developed by Hernandez-Sancho et al. (2011a) [9]. In this model, the performance index $(\mathrm{Z})$ and energy cost indicator $(\mathrm{ECI})$ which is derived from "Z" have been figured out. The performance index $(\mathrm{Z})$ comprises of operational flow rate $(\mathrm{Q})$ $\left(\mathrm{m}^{3} / \mathrm{d}\right)$ and the design flow rate $(\mathrm{q})\left(\mathrm{m}^{3} / \mathrm{d}\right)$ of the WWTP. Eq. 1 shows the calculation of the performance index [2].

$Z=\frac{|\mathrm{q}-\mathrm{Q}|}{Q} .100$ 
Energy cost indicator (ECI) is derived from the performance index $(\mathrm{Z})$, the model includes the volume of treated wastewater per year $(\mathrm{V})\left(\mathrm{m}^{3} /\right.$ year) and biological oxygen demand $\left(\mathrm{BOD}_{5}\right)$ $\left(\mathrm{g} / \mathrm{m}^{3}\right)$. In this study, ECI values of design organic load (ECI organic load, design) and operational organic load (ECI organic load, operational) were figured out and benchmarked with each other. In this term, the variable parameter is $\mathrm{BOD}_{5}$ that means to the required oxygen quantity for the stabilization and the degradation of the organic matters such as carbon, proteins and fats by the microorganisms in the wastewater. It also corresponds to the organic load in other words. The calculation tool of ECI for small scale WWTPs was given below (Eq.2) [2, 9].

$\mathrm{ECI}=1983.10^{6} \mathrm{~V}^{0.717} \mathrm{e}^{\left(-14.327 \mathrm{BOD}_{5}+0.660 \mathrm{Z}\right)}$

\section{Results}

The results revealed that energy cost indicator of operational organic load was higher than the design one whose values were $2.1 \times 10^{-8}$ and $7.2 \times 10^{-18}$, respectively. Figure 2 shows the assessment of the indicators.

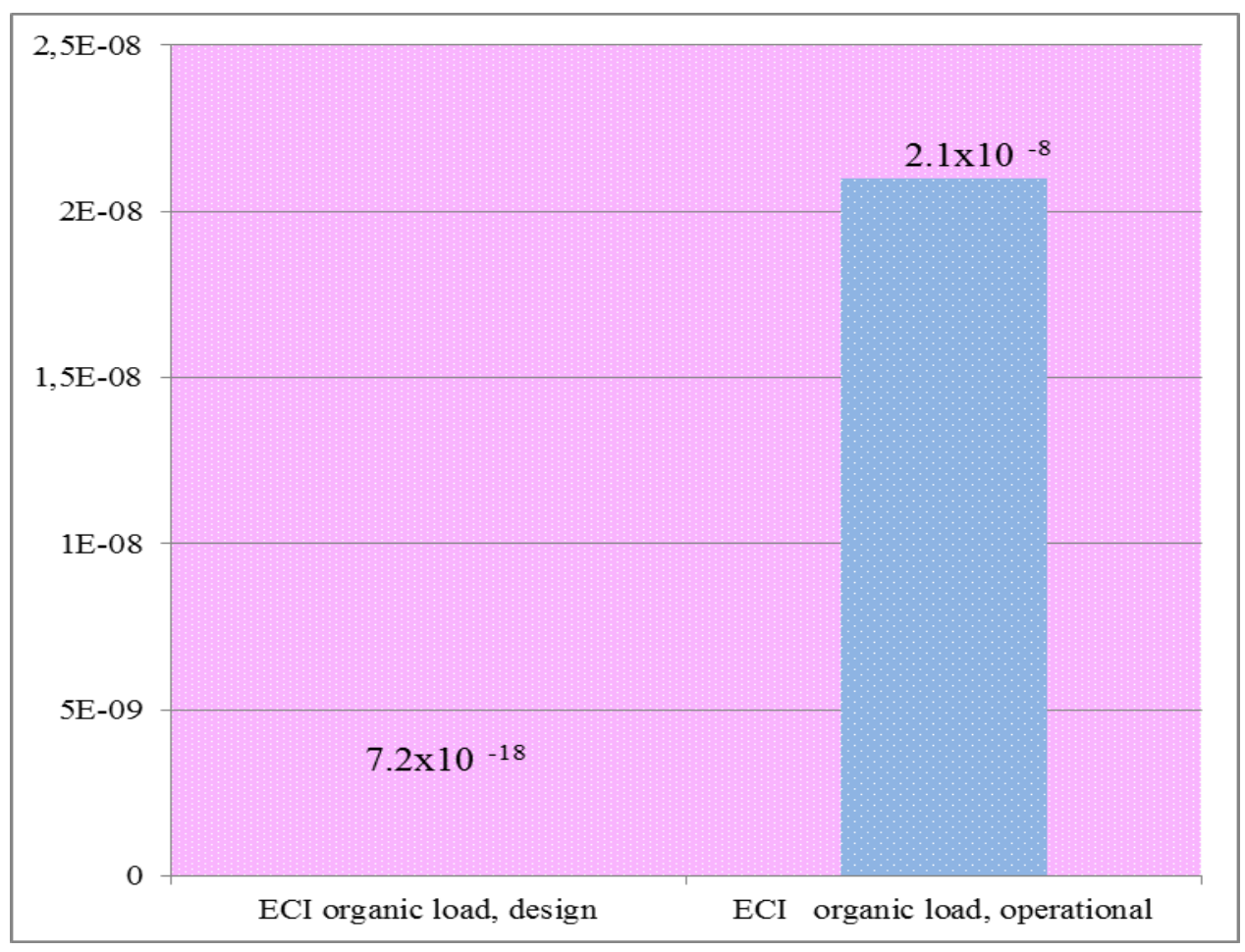

Figure 2. Energy cost assessment of the dairy industry 
$\mathrm{BOD}_{5}$ is the meaning of biological oxygen demand for the degradation of the organic matters in the wastewater. It is an indicator parameter of organic load in terms of wastewater treatment. According to the model, if organic load $\left(\mathrm{BOD}_{5}\right)$ is lower, the cost indicator is higher on the contrary. As a result, if the WWTPs are operated under the conditions of design parameters, energy cost indicator would be lower.

\section{Discussion}

There are many studies corresponds to this topic. The use of cost functions is generally used in the literature. Most of developed models for the wastewater treatment process have been implemented to estimate the operational and maintenance costs of the processes. HernandezSancho et al. (2011b) [10] used a cost modelling methodology applying statistical information for 341 wastewater treatment plants in Spain.

Castellet-Viciano et al. (2018) [2] analysed the impact of design flow on energy costs for small, middle and large scale of WWTPs. They found that $Z$ was $0.20,0.40,0.60$ and 0.80 for smallscale plants. Similarly, $\mathrm{Z}$ value was 0.667 , in this study.

Molinos-Senante et al. (2013) [11] applied a cost function model to estimate the cost of the sludge and waste management. The cost functions for extended aeration and activated sludge also contain the volume of wastewater treated and the biological oxygen demand removal efficiency in \%. The other study corresponds to Molinos-Senante et al. (2018) [12]. They used the energy intensity (EI) model for 305 WWTPs grouped into five secondary treatment technologies. Plumlee et al. (2014) [13] investigated the cost of the advanced treatment, and recently Yumin et al. (2016) [14] figured out the operational cost of WWTPs in rural areas. Silva and Rosa (2015) [15] and Verrecht et al. (2010) [16] reported an over cost for the WWTPs.

\section{Conclusions}

This study shows that energy cost indicator and the performance index can be used as a calculation tool to determine the energy costs of a wastewater treatment plant.

The results show that energy cost indicator of operational organic load was higher than the design one. Their values were $2.1 \times 10^{-8}$ and $7.2 \times 10^{-18}$, respectively.

If organic load that is closed with $\mathrm{BOD}_{5}$ parameter is lower, the energy cost indicator is higher, on the contrary. So if the plants are operated under the conditions of design parameters, energy costs would be lower. 


\section{References}

[1] Metcalf and Eddy. Wastewater Engineering: Treatment and Resource Recovery, 5th ed., McGraw-Hill International Editions, Newyork, USA; 2014.

[2] Castellet-Viciano L, Torregrossa D, Hernández-Sancho F. The relevance of the design characteristics to the optimal operation of wastewater treatment plants: Energy cost assessment J Env Mng 2018;222:275-283.

[3] Racoviceanu AI, Karney BW, Kennedy CA, Colombo AF. Life-cycle energy use and greenhouse gas emissions inventory for water treatment systems. J Infrastruct Syst 2007;13: 261-270.

[4] Tchobanoglous G, Burton FL, Metcalf \& Eddy. Wastewater Engineering: Treatment, Disposal, and Reuse, third ed. McGraw-Hill Education, New York, 1991.

[5] Ozturk I, Eroglu V, Ubay G, Demir I. Hybrid upflow anaerobic sludge blanket reactor (HUASBR) treatment of dairy effluents. Water Science and Technology 2003;28( 2):7785 .

[6] Demirel B, Yenigun O, Onay T.T. Anaerobic treatment of dairy wastewaters: a review. Process Biochemistry 2005; 40(8):2583-2595.

[7] Baskaran K, Palmowski LM, Watson BM. Wastewater reuse and treatment options for the dairy industry. Water Science and Technology: Water Supply 2003; 3(3):85-91.

[8] Standard Methods for the Examination of Water and Wastewater, 20th ed., American Public Health Association/American Water Works Association/Water Environment Federation, Washington DC, USA, 1998

[9] Hernandez-Sancho F, Molinos-Senante M, Sala-Garrido R. Cost modelling for wastewater treatment processes. Desalination 2011; 268, 1-5.

[10] Hernández-Sancho F, Molinos-Senante M, Sala-Garrido R. Energy efficiency in Spanish wastewater treatment plants: a non-radial DEA approach. Sci. Total Environ. 2011;409: 2693-2699.

[11] Molinos-Senante M, Hernandez-Sancho F, Sala-Garrido R. Cost modeling for sludge and waste management from wastewater treatment plants: an empirical approach for Spain. Desalin Water Treat. 2013; 51: 5414-5420.

[12] Molinos-Senante M, Sala-Garrido R, Iftimi A. Energy intensity modeling for wastewater treatment technologies. Sci. Total Environ. 2018; 630: 1565-1572.

[13] Plumlee MH, Stanford BD, Debroux J, Hopkins DC, Snyder SA. Costs of advanced treatment in water reclamation. Ozone Sci. Eng. 2014; 36: 485-495.

[14] Yumin W, Lei W, Yanhong F. Cost function for treating wastewater in rural regions. Desalin Water Treat. 2016; 57: 17241-17246.

[15] Silva C, Rosa MJ. Energy performance indicators of wastewater treatment: a field study with 17 Portuguese plants. Water Sci. Technol. 2015; 72:510-519.

[16] Verrecht B, Maere T, Nopens I, Brepols C, Judd S. The cost of a large-scale hollow fibre MBR. Water Res. 2010; 44 (18): 5274-5283. 